\title{
BIOTIC (FORAMINIFERA AND THECAMOEBIANS) AND ABIOTIC PARAMETERS AS PROXIES FOR IDENTIFICATION OF THE ENVIRONMENTAL HETEROGENEITY IN CAETÉ RIVER ESTUARY, AMAZON COAST, BRAZIL
}

\author{
Lazaro luiz Mattos Laut ${ }^{1, *}$, Maria Virgínia Alves Martins, ${ }^{2,3}$ Fabrizio Frontalini ${ }^{4}$, PierRe Belart ${ }^{1}$, \\ VAldenira F. SANTos ${ }^{5}$, Maria Lúcia Lorini ${ }^{6}$, RAFAel R. ForTes ${ }^{6}$, Frederico S. Silva ${ }^{7}$, Susane S.S. Vieira ${ }^{8}$ ANd \\ PEDRO W.M. SOUZA FILHO 8,9
}

1 Universidade Federal do Estado do Rio de Janeiro - UNIRIO, Laboratório de Micropaleontologia - LABMICRO, Av. Pasteur 458, s. 500, Urca, Rio de Janeiro, RJ, Brazil, CEP 22290-240, lazarolaut@hotmail.com, pbelart@gmail.com

2 Universidade do Estado do Rio de Janeiro - UERJ, Departamento de Estratigrafia e Paleontologia. Av. São Francisco Xavier, 524, sala 2020A, Maracanã. Rio de Janeiro - RJ, Brazil, CEP 20550-013, virginia.martins@ua.pt

3 GeoBioTec, Departamento de Geociências, Universidade de Aveiro, Campus de Santiago, 3810-193, Aveiro, Portugal

4 Università degli Studi di Urbino "Carlo Bo", Dipartimento di Scienze della Terra, della Vita e dell'Ambiente (DiSTeVA), Campus Scientifico Enrico Mattei. Località Crocicchia, 61029 Urbino, Italy, fabrizio.frontalini@uniurb.it

5 Instituto de Pesquisas Científicas e Tecnológicas do Estado do Amapá, Centro de Pesquisas Aquáticas - IEPA/CPAq. Rod. JK, km 10, 68902-280, Fazendinha, Macapá, Amapá, Brazil, valdeniraferreira@gmail.com

6 Universidade Federal do Estado do Rio de Janeiro - UNIRIO, Laboratório de Ecologia Bêntica, Universidade Federal do Estado do Rio de Janeiro - UNIRIO. Av. Pasteur 458, s. 411, Urca, Rio de Janeiro, RJ, Brazil, CEP 22290-240, rafaelfortes@hotmail.com, mluc.lorini@gmail.com

7 Universidade Federal do Rio de Janeiro - UFRJ Laboratório de Palinofácies \& Facies Orgânica. Av. Athos da Silveira Ramos, 274 - Bloco F Ilha do Fundão - Cidade Universitária, Rio de Janeiro - RJ, Brazil, CEP 21949-900, fsobrinho@gmail.com

8 Universidade Federal do Pará - UFPA, Faculdade de Oceanografia. Av. Augusto Correa 1. Caixa Postal 8608, Belém, Pará, Brazil, CEP 66075-110, susane@ufpa.br

9 Instituto Tecnológico Vale, Desenvolvimento Sustentável - ITV. Rua Boaventura da Silva, nº 955, $3^{\circ}$ andar (Nazaré) Belém, Pará, Brazil, 66055-090,walfir@ufpa.br

*CorResponding AUTHOR, lazarolaut@hotmail.com

Received on 15 December 2015

Received in revised form on 20 January 2016

Accepted on 26 January 2016

Editor:

Herminio Ismael de Araújo-Júnior, Universidade do Estado do Rio de Janeiro, Brazil

\section{Abstract}

Foraminifera and thecamoebians assemblages were analyzed at Caeté River Estuary in order to identify saline gradients and intensity of human impacts. In the study area, 29 species of foraminifera typically from intertidal environments and 11 species of thecamoebians were identified. The microfaunal assemblages were characterized by low diversity, averaging 1.9 at the mouth and 0.5 near Bragança City. These values are common in transitional coastal environments along de Brazilian Coast. Statistical analysis, based on the relative abundance of species, did not reveal the presence of an estuarine gradient, which was corroborated by the physical and chemical parameters measured in the field. An increasing of sedimentary fine fraction and organic matter occurs in the intermediate
Citation:

Laut, L.L.M., Martins, M.V.A., Frontalini, F., Belart, P., Santos, V.F., Lorini, M.L., Fortes, R.R., Silva, F.S., Vieira, S.S.S., Souza-Filho, P.W.M., 2016. Biotic (foraminifera and thecamoebians) and abiotic parameters as proxies for indication of the environmental heterogeneity in Caeté River Estuary, Amazon Coast, Brazil. Journal of Sedimentary Environments, 1(1): 1-16.

region of the estuary, indicating attenuation of the stream influence.

The calcareous foraminifera species were associated with high salinity, temperature and $\mathrm{pH}$ values. The agglutinated species were associated with muddy sediment, total organic matter and lower salinity. Four environmental compartments were identified based on biotic and abiotic analysis, but they do not represent the classic estuarine gradient, instead, they represent the differences in the freshwater supply and mangrove distance.

Keywords: Microfauna. Microtidal estuary. Sedimentology. Coastal dynamics. 


\section{Introduction}

Foraminifera and thecamoebians are considered valuable bioindicators of ecological and environmental conditions in estuaries (Scott et al., 2001). Their assemblage compositions are associated with environmental features such as oxygen, depth, and grain size, as well as anthropogenic impacts such as those originated by organic disposal, heavy metals or hydrocarbons (Schafer, 1991; Alve, 1995). The mixing of sea water with freshwater is detected by changes in assemblage composition, diversity and abundance that suggest that some features such as tidal range and fluvial discharge, can quantitatively be monitored by the living biota (Bonetti and Eichler, 1997).

Valuable studies about foraminiferal assemblages on macrotidal estuaries have been performed to identify the zonation in tidal plains, and to detect changes of the relative sea level during the Quaternary, such as in Argentina (Scott et al., 1990), Australia (Wang and Chappell, 2001) and France (Debenay et al., 2003). Scott et al. (1990) documented the recent foraminiferal zonation on tidal plains at similar latitudes in both South America and the Northern Hemisphere. According to Scott et al. (1990), the fauna was similar in both hemispheres, and the topographic (tidal plain/sea level) relationships among species from the Northern Hemisphere was also valid in the same environments of the Southern Hemisphere.

Wang and Chappell (2001) evaluated the potential of the foraminiferal assemblages to be used as proxies to study the relative sea level changes during the Holocene. In the main channel of this estuary, a zonation showing a smooth decrease of porcelaneous foraminifera, an increase of hyaline species and brackish foraminifera were observed. Paleoenvironmental interpretations were performed using both foraminiferal assemblages as palynological data.

The microfauna of foraminifera and thecamoebians from Brazilian estuaries have been studied since 60's. However, most of these studies were done at coastal zones influenced by a microtidal regime (Closs, 1964; Brönnimann et al., 1981a, b, c; Eichler and Bonetti, 1995; Laut et al., 2007, 2011a, 2011b; Leipnitz et al., 2014). Only a study at a macrotidal estuary was done by Laut et al. (2010) in the Araguari River, located on the coast of Amapá State. In this study, the authors used foraminiferal and thecamoebian assemblages and palynomorphs to compartmentalize the estuary and to identify the upper limit of the tidal bore transport of sediments.

In view of the importance of these microorganisms and the scarce knowledge about them as bioindicators, this study seeks to document foraminiferal and thecamoebian species distribution in Caeté River Estuary and to identify ecological compartments that can be used as the basis for ecological and paleontological studies in macrotidal regions of Brazil.

\section{Material and methods}

\subsection{Study area}

The investigated estuary is located in northern Brazil approximately $380 \mathrm{~km}$ southeast of the mouth of the Amazon River (Figure 1), and it is inserted in the largest continuous mangrove belt in the World (Souza Filho et al., 2005; Nascimento Jr. et al., 2013). The tectonics and structure of this basin are responsible for the submergence of this coastal zone region (Souza Filho, 2000).

Geologically, the Caeté River Estuary is inside the coastal basin of Bragança-Viseu that was formed during the Cretaceous, and shows an evolution controlled by normal faults (Souza Filho, 2000). During the Holocene, this coast submerges with the fluvial sediment supply, while the relative sea level drops (Souza Filho and El-Robrini, 1996; Souza Filho et al., 2009), allowing the progradation of the muddy plain and the development of the most extensive mangrove system in the world (Cohen et al., 2005; Souza Filho et al., 2006). The coastal plain extends northward for more than $25 \mathrm{~km}$, where a great system of muddy tidal plains, salt marshes, sandy tidal plains, cheniers, sandy dunes, barrier islands and ebb tidal deltas are found (Souza Filho and Paradella, 2002).

The climate is classified as hot and humid (Fisch et al., 1998) with two seasons, rainy (January to July) and dry (August to January), which have an average rainfall of 2000 $\mathrm{mm}$ and $20 \mathrm{~mm}$, respectively (Monteiro et al., 2009). The region boasts a semidiurnal macrotidal regime with minimum variations of $1.8 \mathrm{~m}$ and maximum variations of $5.4 \mathrm{~m}$ (Souza Filho et al., 2009).

Strong tidal currents and waves are responsible for the erosion of mangrove forests along the coast, estuary and bays, where the fallen tree lines mark the erosion range. These currents are stronger during the syzygy tide, which can reach speeds of $1.5 \mathrm{~m} / \mathrm{s}$ (Cohen et al., 1999). On the other hand, new mangrove fringes are formed seaward as a result of mud sedimentation (Souza Filho and El-Robrini, 1998).

The water salinity at the estuary ranges from 1.41 to $35.25 \%$; the dissolved oxygen ranges from 0.86 to 17.69 $\mathrm{mg} / \mathrm{l}$ (Magalhães et al., 2006); and the water temperature ranges from $27^{\circ}-30^{\circ} \mathrm{C}$ (Diele and Smith, 2006). 

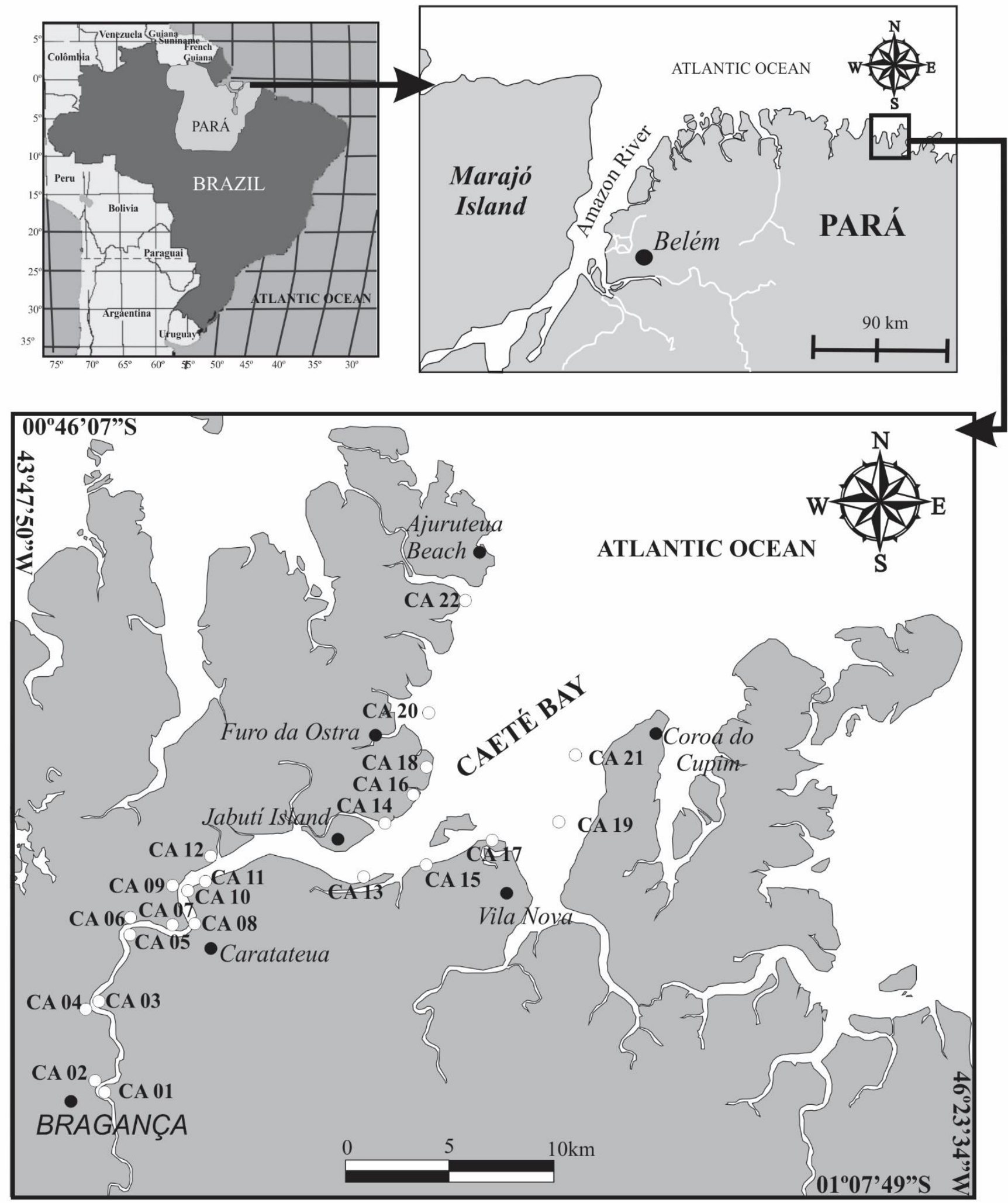

Fig. 1. Studied area and samples in Caeté River Estuary, Pará Coast. 
Mangroves in the region are dominated by Rhirophora mangle, Laguncularia racemosa, $\mathrm{R}$. harrisonii, Avicennia germinans and A. schaueriana species (Menezes et al., 2008). The terrain slope at this region provides a gradient related to flood frequency, which allows the formation of three different mangrove zones. Zone I, less flooded and consequently more saline, is composed only by $A$. germinans. Zones II and III, which are lower regions frequently flooded and with lower interstitial salinity, are inhabited by the three typical species of mangrove. These two zones are only differentiated by litter production (Menezes et al., 2008).

At the Caeté estuary, two types of impact agents can be identified. One is of natural origin, related to tidal action and waves that reach heights of about $2 \mathrm{~m}$, which lead to erosive processes (Souza Filho and Paradella, 2003); and the other associated with anthropogenic impacts, which increased in the early 80's due to the construction of a road connect Bragança City to Ajuruteua Beach. This road was built on extensive muddy deposits densely occupied by mangroves, along $25 \mathrm{~km}$ (Souza Filho and Paradella, 2003). This road interrupted several tidal channels, not allowing nutrient circulation in the mangrove environment, and acted in some parts as a dam for tidal dynamics, creating huge areas with dammed water (Fernandes, 2005).

\subsection{Sampling}

Twenty-two sediment samples were collected in August of 2006, from the mouth of Caeté River to the outskirts of Bragança City, using a van Veen sampler (Figure 1). For the foraminiferal and thecamoebian analyses, $150 \mathrm{ml}$ from the uppermost $1 \mathrm{~cm}$ of sediment were sampled. The sediment was stored in plastic pots filled with $70 \%$ alcohol with rose bengal stain $(2 \mathrm{~g} / \mathrm{L})$ to avoid bacterial degradation of the sample and for identification of living organisms at the time of sampling.

A volume of $\sim 300 \mathrm{~g}$ of the sediment was stored in identified plastic bags for sediment analysis. At the field, physicochemical parameters of bottom water, such as salinity, temperature and $\mathrm{pH}$ were measured. For salinity measurements, a refractometer, American Optical model 10419, was used. The $\mathrm{pH}$ was measured with a Schott Gerate Meter CG837.

\subsection{Sedimentological analysis}

For grain size analysis, $100 \mathrm{~g}$ of sediment collected at each station were washed with distilled water to eliminate soluble salts, and later dried in an oven at a temperature of $50^{\circ} \mathrm{C}$. After this phase, these samples were treated with $30 \%$ hydrogen peroxide for organic matter removal. The sandy fractions $(>0.062 \mathrm{~mm})$ were sieved at each 0.5 phi. The fine fractions $(<0.063 \mathrm{~mm})$ were analyzed by the pipette method (Suguio, 1973). The grain size classification was based on Flemming (2000), which is restricted to sediments $<2 \mathrm{~mm}$. For this classification, the triangular diagram, which is also used by other classifications, was adopted, although it entails more subdivisions, allowing a more detailed analysis of the sediment grain size.

Total organic matter content (TOM) was analyzed by the loss on ignition method (LOI), which is based on sequential heating of the samples in a muffle furnace. Fifty grams of dry sample were oven dried for 24 hours at a temperature above $60{ }^{\circ} \mathrm{C}$. Afterwards, the dry sediment was weighed and burned in a muffle furnace at $500{ }^{\circ} \mathrm{C}$. After 4 hours the sample was weighed again. TOM was determined by the difference between the initial and the final weight (Byers et al., 1978).

\subsection{Microfaunal analyses}

The samples used for benthic foraminifera and thecamoebians were washed through $0.063 \mathrm{~mm}$ and 0.5 $\mathrm{mm}$ sieves, and the other fractions were discarded (Boltovskoy, 1965). After being dried in an oven at $50^{\circ} \mathrm{C}$, specimens were separated by flotation with carbon trichloroethylene $(\mathrm{C} 2 \mathrm{HCl} 3)$. The specimen picking and counting were carried out under a stereo microscope, and the number of specimens per species found in each station was recorded. Living and dead individuals were counted separately to provide information on living microfauna, but only the dead assemblages were used in this study.

We chose to consider the dead assemblages because (1) the low abundance of living benthic foraminifera; (2) seasonal variability is smoothed and (3) hydrodynamic influence is better constrain in the study area. Taxonomic identification of the microorganisms was based on Todd and Brönniman (1957), Boltovskoy et al. (1980), Scott and Medioli (1980), Loeblich and Tappan (1987), and Debenay et al. $(2002,2004)$.

All samples with at least 100 specimens were considered for statistical analyses because they may provide reliable results concerning species representativeness in the assemblage composition (Fatela and Taborda, 2002). The relative abundance of the species at each sample was used to calculate ecological indices. Considering the low number of specimens of thecamoebians, which could 
prevent statistical analysis, and considering the importance of this group of protozoans, they were combined and analyzed together with foraminifera.

Diversity was calculated using the Shannon-Wiener $\left(\mathrm{H}^{\prime}\right)$ index, expressed by the formula: $\mathrm{H}^{\prime}=\sum \mathrm{pi}$ lnpi. The mean evenness (or homogeneity) was calculated by the formula: $\mathrm{J}^{\prime}=\mathrm{H}^{\prime} / \ln (\mathrm{S})$ using the software MVSP 3.1.

\subsection{Multivariate analysis}

In order to evaluate the similarity among sampled stations and to identify meso-scale environments according to faunal distribution, Q-mode and R-mode cluster analysis with the software Pcord5 was performed. The distance matrix was generated considering the relative abundance of all identified species, standardized to the square root of 0.5 in order to decrease the difference between dominant and rare species. The Euclidean distance coefficient and Ward's method for station amalgamation were used in order to do a comparative evaluation among stations.

In order to understand the interdependent relationships that may exist between all analyzed environmental variables and their influence on ecological relationships and on foraminiferal and thecamoebian species distribution, a multivariate analysis known as Detrended Correspondence Analysis (DCA) was performed with the software PCord5.

The relative Euclidean Distance was applied to calculate the variance, which is recommended in order to measure the ordination in space. In order to normalize all data, the square root (of 0.5) was applied, using Software PCord5.

\section{Results}

Among the physicochemical parameters, salinity showed the highest variation (Table 1$)$. The lowest value occurred at station CA04 (0.1\%o), located in the inner zone of the Caeté River estuary, and the highest (21.9 $\%$ ) at station CA17, located at the Caeté Bay (Table 1, Figure 1). The inner part of the estuary within Jabutì Island was characterized by relatively low salinity values, commonly lower than $10 \%$ (Table 1 ).

The $\mathrm{pH}$ values varied mostly between 6.02 and 6.97, indicating slightly acid conditions. Only one relatively high $\mathrm{pH}$ (8.0) value was recorded at station CA07 (Table 1, Figure 1). Temperature varied in the estuary, from $26.6{ }^{\circ} \mathrm{C}$ at station CA01 located next to Bragança City, to $30.6{ }^{\circ} \mathrm{C}$ at station CA06 (Table 1, Figure 1).

Tab. 1. Physicochemical parameters recorded in the studied stations of Caeté River Estuary.

\begin{tabular}{cccc}
\hline Stations & Temperature $\left({ }^{\circ} \mathbf{C}\right)$ & Salinity $(\% \mathbf{~})$ & $\mathbf{p H}$ \\
\hline CA01 & 26.6 & 0.4 & 6.06 \\
CA02 & 28.4 & 0.7 & 6.54 \\
CA03 & 27.1 & 0.2 & 6.09 \\
CA04 & 28.3 & 0.1 & 6.04 \\
CA05 & 28.7 & 7.6 & 6.70 \\
CA06 & 30.6 & 8.2 & 6.20 \\
CA07 & 29.6 & 6.8 & 8.00 \\
CA08 & 30.6 & 8.9 & 6.45 \\
CA09 & 31.0 & 10.7 & 6.15 \\
CA10 & 30.5 & 9.3 & 6.02 \\
CA11 & 29.3 & 7.3 & 6.16 \\
CA12 & 28.7 & 8.1 & 6.17 \\
CA13 & 28.8 & 17.6 & 6.42 \\
CA14 & 29.1 & 18.0 & 6.69 \\
CA15 & 29.8 & 18.7 & 6.73 \\
CA16 & 29.9 & 20.0 & 6.56 \\
CA17 & 28.3 & 21.9 & 6.97 \\
CA18 & 29.8 & 19.4 & 6.41 \\
CA19 & 28.7 & 18.0 & 6.59 \\
CA20 & 28.1 & 19.0 & 6.45 \\
CA21 & 29.2 & 18.0 & 6.09 \\
CA22 & 29.5 & 17.0 & 6.79 \\
\hline
\end{tabular}

Grain size analysis showed that the sand is the dominant fraction in the estuary except at station CA15, with approximately $100 \%$ of fine grains (Figure 2). Stations CA03 and CA04 located in the inner part of the estuary, and CA19, CA20, CA21 and CA22, located in Caeté Bay, showed $100 \%$ of sandy fraction (Figure 2 ).

The classification scale for sorting degree showed that sediments varied from moderately to poorly sorted. Wellsorted sediments were found only in stations CA03 and CA04. Most of the studied stations at the Caeté Estuary were characterized by sandy sediments (Figure 2). 


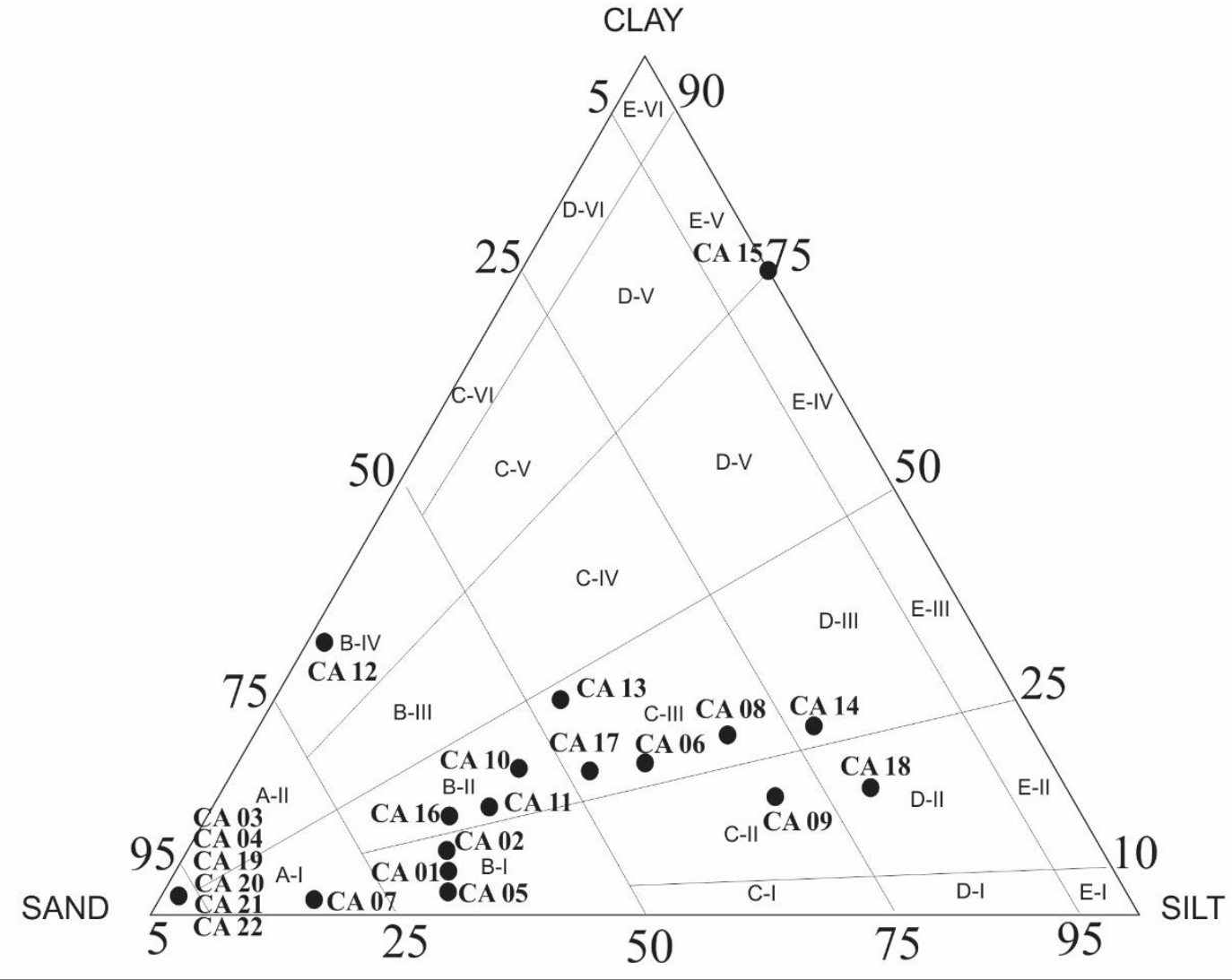

\begin{tabular}{lrrrllc}
\hline \hline Stations & $\begin{array}{r}\text { Sand Silte } \\
\text { (\%) }\end{array}$ & & Slay & Flemming Classification & $\begin{array}{c}\text { Organic Matter } \\
\text { (\%) }\end{array}$ \\
\hline \hline CA 01 & 66 & 27 & 7 & Moderatedy sorted & Very silty sand & 1.6 \\
CA 02 & 66 & 25 & 9 & Moderatedy sorted & Very silty sand & 1.92 \\
CA 03 & 100 & 0 & 0 & Well sorted & Sand & 0 \\
CA 04 & 100 & 0 & 0 & Well sorted & Sand & 0 \\
CA 05 & 68 & 29 & 3 & Moderatedy well sorted & Very silty sand & 0.3 \\
CA 06 & 41 & 41 & 18 & Moderatedy sorted & Silty sandy mud & 0 \\
CA 07 & 82 & 16 & 2 & Moderatedy well sorted & Slightly silty sand & 0.48 \\
CA 08 & 31 & 48 & 21 & Moderatedy sorted & Silty sandy mud & 5.84 \\
CA 09 & 30 & 56 & 14 & Poorly sorted & Very silty sandy mud & 0.02 \\
CA 10 & 54 & 29 & 17 & Poorly sorted & Silty sand & 0.56 \\
CA 11 & 59 & 28 & 13 & Poorly sorted & Silty sand & 0 \\
CA 12 & 66 & 2 & 32 & Poorly sorted & Very clayey sand & 0.12 \\
CA 13 & 48 & 26 & 26 & Poorly sorted & Silty sandy mud & 0 \\
CA 14 & 22 & 56 & 22 & Poorly sorted & Silty slightly sandy mud & 0.08 \\
CA 15 & 0 & 25 & 75 & Poorly sorted & Slightly silty clay & 2.22 \\
CA 16 & 64 & 25 & 11 & Poorly sorted & Silty sand & 0.68 \\
CA 17 & 47 & 36 & 17 & Poorly sorted & Silty sandy mud & 0 \\
CA 18 & 20 & 65 & 15 & Moderatedy sorted & Very silty slightly sandy mud & 3.06 \\
CA 19 & 100 & 0 & 0 & Moderatedy well sorted & Sand & 0.06 \\
CA 20 & 100 & 0 & 0 & Moderatedy well sorted & Sand & Sand \\
CA 21 & 100 & 0 & 0 & Moderatedy well sorted & Sand & 0.42 \\
CA 22 & 100 & 0 & 0 & Moderatedy well sorted & Sand & 0.14 \\
\hline
\end{tabular}

Fig. 2. Result of sedimentological analysis in the studied stations of Caeté River Estuary. 
The percentage of total organic matter ranged from $5.84 \%$ at station CA08, to $0 \%$ at stations CA03, CA04, CA06, CA11, CA13 and CA17, composed of coarse grained sediments (Figure 2).

A total of 29 foraminiferal and 11 thecamoebian taxa were identified. The test density (test number of both foraminifera and thecamoebians in $150 \mathrm{ml}$ of sediment) at each station ranged from 150 at station CA13 to 3399 at station CA14 (Table 2). Low abundance of foraminifera was also found in stations CA01 (261), CA03 (168), CA07 (240), CA09 (151), CA17 (216) and CA19 (154). Stations CA20 and CA21 were devoid of tests.

Agglutinated (Textulariida Order) foraminifera were dominant along the estuary. The most frequent species, which reached the highest values of relative abundance were: Arenoparrella mexicana (6 - 89.1\%), Haplophragmoides wilberti $(2.2-20 \%)$, Entria polystoma (up to 18.8\%) and Miliammina fusca (up to 87.3\%) (Table 2). Some species, such as Warrenita palustris, Trochammina inflata, Entria macrescens, Textularia earlandi and Siphotrochammina lobata had a wide distribution along the estuary, although very low relative abundance (Table 2). Only four calcareous species of foraminifera were identified: Ammonia tepida, Bolivinellina translucens, Cribroelpbidium excavatum and Quinqueloculina seminula. Among these taxa, only A. tepida was identified in more than one station (CA11, CA12 and CA16) located at the estuary entrance. The other calcareous species were restricted to station CA16 (Table 2).

The species of thecamoebians were irregularly distributed along the estuary, with an overall low relative abundance $(0.3-3.8 \%)$. The highest number of species was identified at the inner region of the estuary and at stations located close to the river mouth. The most abundant species along the estuary were: Difflugia urceolata, Difflugia oblonga and Pontigulasia compressa (Table 2).

Stain tests were done at eleven stations $\quad<7$ specimens). The highest abundance was found at CA10 and CA16 (Table 2). Abnormal tests were identified on all stations along the Caeté Estuary, but with low percentages. Stations CA15 (32 tests) and CA10 (22 tests) showed the highest amount of abnormal tests, belonging mainly to $A$. mexicana and $M$. fusca species (Table 2). The $H^{\prime}$ index varied between 0.5 and 1.9, indicating a low degree of biodiversity along the estuary. The highest value, 1.9, was found at station CA18 at Caeté Bay, and the lowest, 0.5, was found at CA03, in the inner estuarine zone. The J' ranged between 0.2 at CA15, and 0.7 at CA13 and CA18 (Table 2). Both maximum and minimum values were recorded in the external sector of the estuary.

Cluster analysis on $\mathrm{R}$-mode revealed the presence of seven assemblages at Caeté Estuary, considering the similarity level of 48\% (Figure 3):

- Assemblage A - composed only of agglutinated foraminifera. The dominant species for this assemblage were A. mexicana, P. ipohalina, T. salsa and Ammoastuta inepta. The species Ammoastuta salsa and P. limnetis were grouped in this assemblage, but were not frequent and showed low relative abundance (Figure 3);

- Assemblage B - composed mainly of foraminiferal $M$. fusca, T. inflata and Ammotium cassis taxa and by the thecamoebians Centropyxis constricta and Cyclopyxis spp., which have relative abundance lower than 5\% (Figure 3);

- Assemblage $\mathrm{C}$ - composed only of species that have relative abundance lower than 5\% (Ammotium salsum, $S$. lobata, E. excavatum, Reophax nana, Difflugia viscidula and P. compressa). Considering these species, only S. lobata and $A$. salsum were present in all the stations (Figure $3)$;

- Assemblage D - composed mainly of H. wilberti and E. macrescens. Other species included in this subcluster were Paratrochammina clossi and Difflugia capreolata, with low relative abundance (Figure 3);

- Assemblage E - was only composed by foraminiferal species; the dominant species of this assemblage were E. polystoma, Tiphotrocha comprimata and Tritaxis squamata. Haplophragmoides manilaensis is a rare species $(>2 \%)$ that was only found in few stations;

- Assemblage F - composed of foraminifera and thecamoebians with low relative abundance and disperse occurrences, such as: T. paranaguaensis, Trochamminita irregularis, D. urceolata and D. oblonga;

- Assemblage G - composed of the foraminiferal species $W$.palustris and T. earlandi that occur with low relative abundance, but which have high frequency at stations. Ammotium pseudocassis and A. tepida also belong to this assemblage, although they have low frequency in the estuary.

Q-mode cluster analysis generated four groups of stations at $87 \%$ level of similarity. Group I was composed by stations CA01, CA02, CA06, CA07, CA08, CA10, CA14 and CA18; Group II by stations CA03 and CA22; 
Group III by stations CA04, CA05, CA09, CA12, CA13, CA16, CA17 and CA19; and Group IV composed only by station CA15 (Figure 3).

The correlation among two cluster analyses (Q-mode and R-mode) showed that Group I was composed of species characteristic of all assemblages; Group II was composed only by assemblage A; Group III was composed of species from assemblages A, B, D and G; and Group IV was composed by assemblages $\mathrm{A}$ and $\mathrm{B}$, characterized by low abundance of $A$. mexicana and high abundance of $M$. fusca (Figure 3).

Station CA15 was excluded from the matrix used in the DCA analysis, since this station presents very high relative abundance of $M$. fusca $(89.9 \%)$ and fine-grained sediments $(100 \%$ of fine fraction content) and aiming to avoid emphasizing the difference between this and other stations.
The singularity of this station among the others can also be observed in the Q-mode cluster analysis (Figure 3). DCA using environmental parameters such as $\mathrm{pH}$, temperature, salinity, TOM and fine fraction content (silt + clay) showed a variance coefficient of $49 \%$ for axis 1 and $23 \%$ for axis 2 (Figure 4). Ammobaculites dilatatus, A. tepida and A. cassis had the most positive covariance with fine sediment, and negative covariance with high $\mathrm{pH}$ values. On the other hand, T. irregularis is positively related with $\mathrm{pH}$ and negatively related with fine fraction (Figure 4).

The main vectors linked to axis 2 were temperature and salinity (Figure 4). Elphidium excavatum, Plagiopyxis spp., $Q$. seminula, B. translucens and $C$. compressa show a stronger positive relationship with these variables, whereas Cyclopyxis spp., T. comprimata, P. compressa and D. viscidula exhibited a negative relationship.

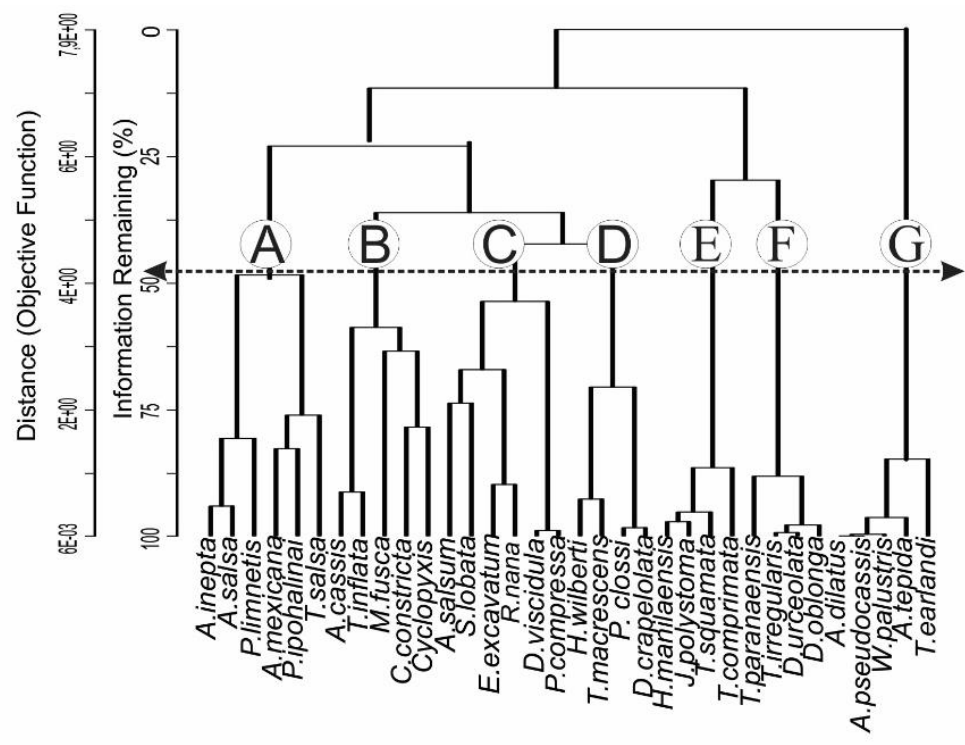

Relative Abundance species/stations
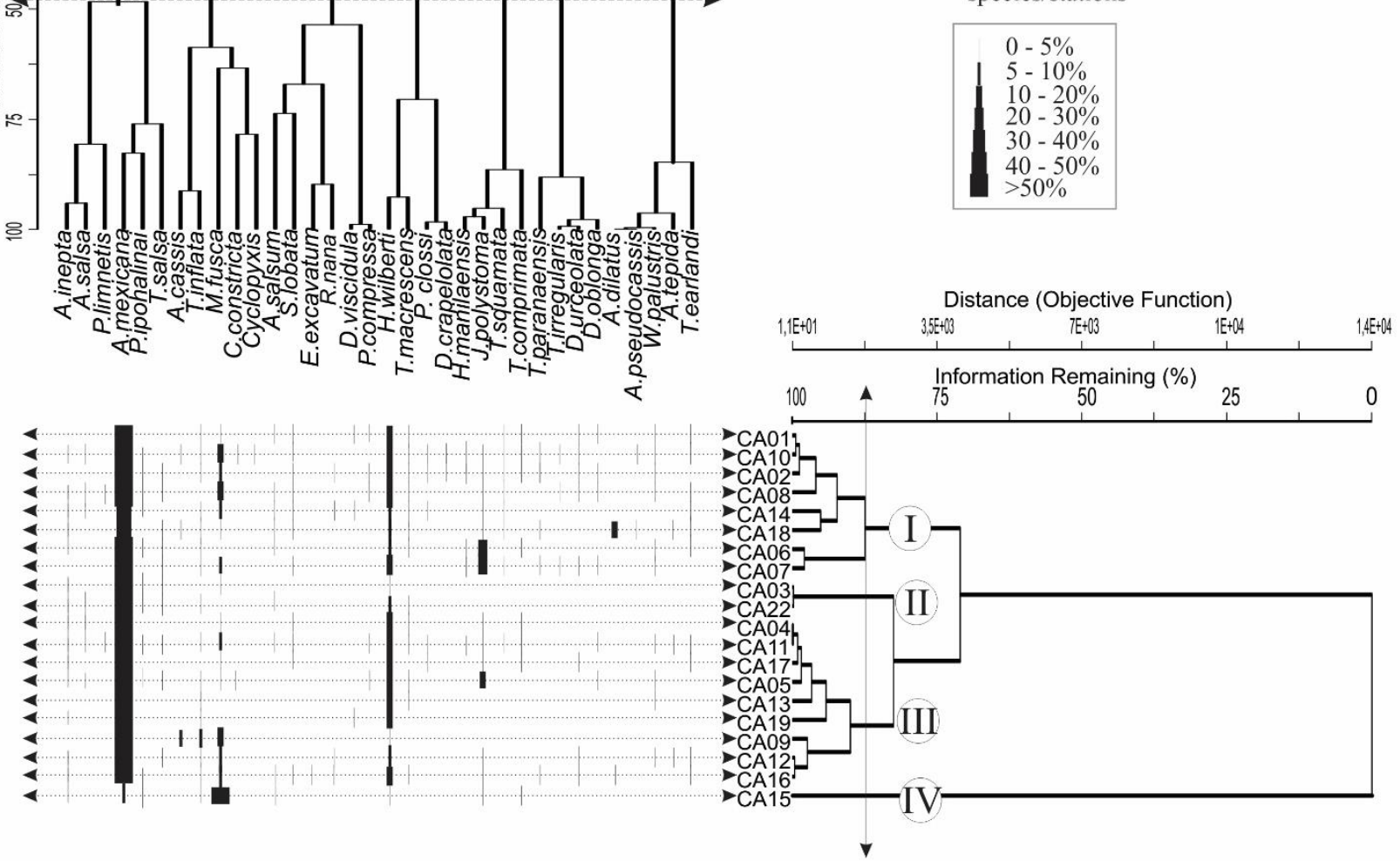

Fig. 3. Cluster analysis in Q-mode and R-mode based on the relative abundance of foraminifera and thecamoebians species from Caeté River Estuary. 


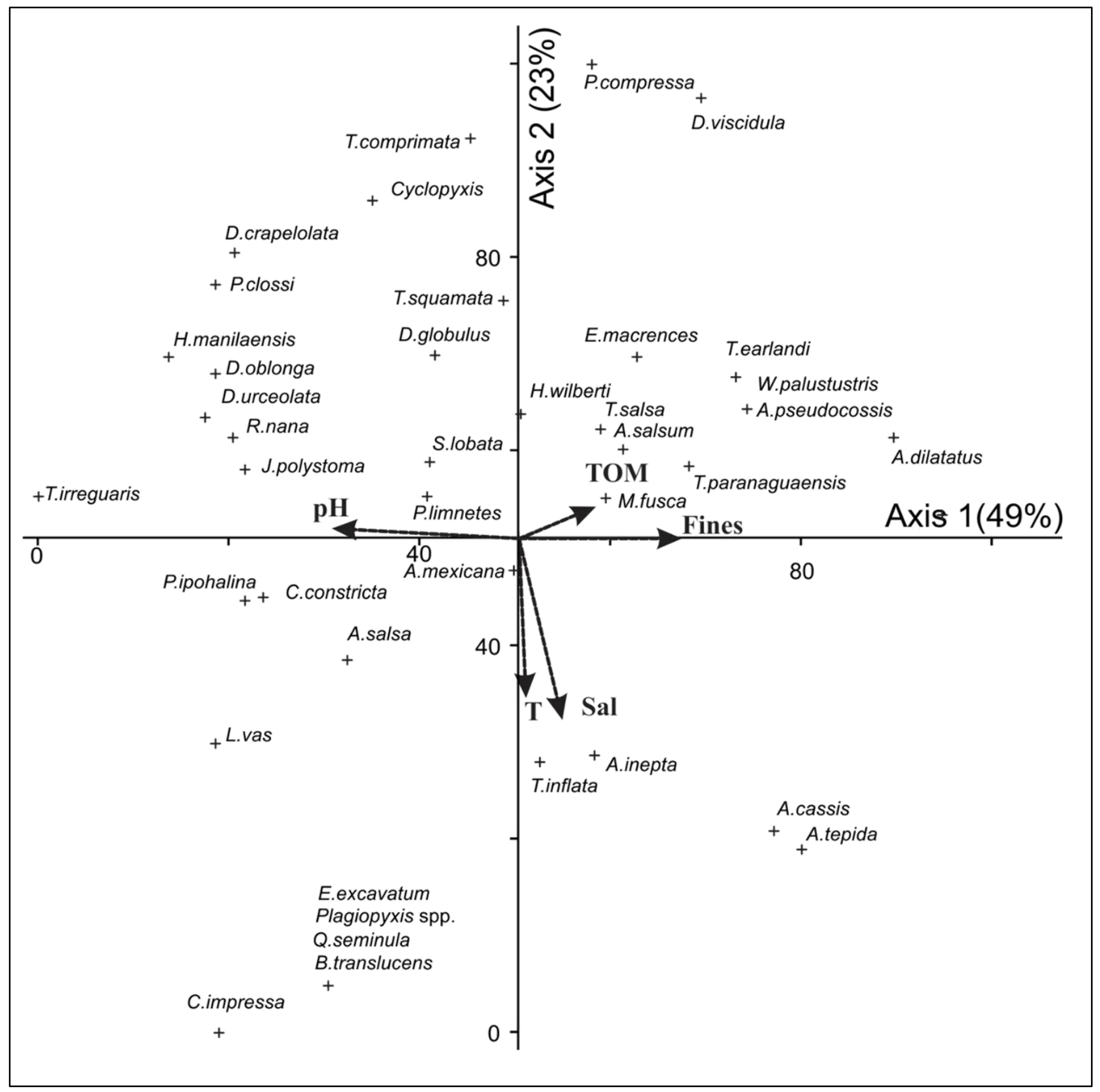

Fig. 4. Detrended Correspondence Analysis (DCA) using the relative abundance of foraminifera and thecamoebians species identified in Caeté River Estuary.

\section{Discussion}

A well-defined gradient of physicochemical parameters from the inner zone of Caeté estuary toward the ocean was not observed. This fact is probably related to tidal influence, which varies along the day, and the proximity of fluvial litter channels. However, the irregular variation of these parameters was also observed by Magalhães et al. 
(2006) in Caeté Estuary. Sediments at the studied stations tended to be acid, probably due to the influence of the dense mangrove forest that borders the entire estuary, producing organic acids through decomposition processes (Laut et al., 2007, 2011a). Moderately sorted to well sorted sandy sediments were largely found in the stations along the estuary, as well as in Caeté Bay (CA19, CA20, CA21 and CA22). The dominance of sandy sediments indicates high hydrodynamism, and consequently, strong oxidation of sediments, which may explain the low concentrations of organic matter found in some stations during sampling. Sampling was carried out during the lower precipitation season (Diele and Smith 2006), which most likely reduced the input of fine grains transported toward the estuary. The time of sampling may also explain the low abundances of the fine fraction and organic matter in the sediment of the studied stations. However, in the intermediate region of the estuary, hydrodynamism seems to be more variable and allows the seasonal deposition of fine grained particles.

According to Walker and Lages (1980), a high diversity of morphotypes of thecamoebians is commonly found in Amazon environments, such as the Caeté River Estuary. Accordingly, the investigation of the bottom sediments of streams within the Amazon rainforest revealed the presence of 119 morphotypes (Walker, 1982). However, a lower diversification was found in the studied stations during the sampling event. Most thecamoebians species have a planktonic habit and it is possible that deposition of these tests will be in regions of low hydrodynamism.

Laut et al. (2010) identified a high thecamoebian species richness at Araguari River Estuary, located in the Amapá coast, which allowed the recognition of the limits of seawater influence. On the other hand, at the Caeté River estuary, these species were identified at all stations, except in the stations located in the outer part of Caeté Bay. The genus Difflugia, dominant along the entire estuary, is generally found in upper estuary regions (Klisa and Schöder-Adams, 1999). The dispersion of this genus through the estuary could indicate a constant freshwater distribution or the potential transport towards the river mouth, as observed by Bonetti and Eichler (1997) at the mouth of Itapitangui River (São Paulo State), Laut et al. (2010) at the mouth of Araguari River (Amapá State) and Laut et al. (2011a) at the mouth of Paraíba do Sul River (Rio de Janeiro State).

Wang and Murray (1983) noticed that in macrotidal estuaries such as the Qiagtan River (China) and the Humber and Severn rivers (England), there is a great amount of exotic foraminifera (from the nearby continental shelf) with small sizes, which cause an increase in assemblage biodiversity. Le Xuan (1996), studying paralic environments in the southern part of Mekong delta (Vietnam), also found a dominance of marine assemblages at the river mouth, which are substituted by $A$. tepida toward the upper estuary. At the estuary of the Loire (France), this pattern was also noted by Debenay and Guillou (2002). However, the Caeté estuary did not fit these patterns. Exotic species were not found and A. tepida was identified only at three stations, with very low relative abundance. The dominance of agglutinated foraminifera, which is typical of paralic areas, was observed along the estuary. These species were identified as dominant ones in other Brazilian estuaries, such as at Itacorubí - Santa Catarina State (Laut et al., 2007), the delta of Paraíba do Sul River (Laut et al., 2011a), Suruí River - Rio de Janeiro State (Laut et al., 2011b), Guaratiba - Rio de Janeiro State (Laut et al., 2012), and Tramandaí Basin in Rio Grande do Sul (Leipnitz et al., 2014), all located in coastal zones with microtidal regimes. The acid $\mathrm{pH}$ identified along the estuary can cause the dissolution of calcareous tests and therefore increase the relative abundance of agglutinated counterparts. The great amount of freshwater typical of the Amazon coastal zone can inhibit the settlement of calcareous species in this macrotidal environment. Assemblages dominated by calcareous species of foraminifera, typical of estuarine environments, are found in this region in the continental shelf as a result of the influence of the Amazonia drainage basin (Vilela and Koutsoukos, 1995).

Arenoparrella mexicana is a dominant species in areas with low salinity of microtidal estuaries, where environmental parameters do not dramatically change (Laut et al., 2012). At the Caeté estuary, A. mexicana was the dominant species on almost all the stations, probably due to the stronger influence of the fluvial processes in the river mouth area than in marine areas, which shows that it exhibits an opportunistic character independent of the tidal range.

Arenoparrella mexicana, H. wilberti, Entria polystoma and $M$. fusca are the most abundant taxa. In particular, these taxa are widely distributed in these environments; in fact, the benthic foraminiferal assemblages at Guaratuba marsh (Southern Brazil) are mainly represented by $A$. mexicana, $T$. inflata and $H$. wilberti, followed by $H$. manilaensis, $E$. macrescens, $M$. fusca, P. limnetis and T. comprimata as minor components (Duleba et al., 2005).

The occurrence of deformed tests along the estuary is likely related to the abrupt environmental changes in this environment. Generally, several authors associate the 
foraminiferal tests deformation with pollution caused by heavy metals and hydrocarbons (Yanko et al., 1994, 1998; Sharifi et al., 1991; Ellison et al., 1986), but this is not the case at Caeté. Geslin et al. (2002) concluded that environmental stress caused by long anoxic periods, salinity changes and hydrodynamism, can also induce deformities in foraminiferal tests. Thus, changes in salinity and hydrodynamism may be related to the significant abundance of deformities in the foraminiferal tests of Caeté River. A relatively higher number of stained tests (living) was found in intermediate regions of the estuary (Table 2), which might suggest more favorable conditions for those living organisms. As observed in this part of the study area, the lower hydrodynamism may allow the deposition of a higher concentration of mud and organic matter. However, the abundance of living organisms in these regions may be underestimated because they are characteristically favorable to microorganism colonization. A certain inefficiency of the use of rose Bengal to stain the protoplasm of agglutinated foraminifera is known. The osmotic stress provoked by the difference between the salinity of the sediment and the solution used can break the cytoplasmic membrane, making it impossible to identify living organisms in the laboratory (Murray and Bowser 2000; Debenay et al., 2001, 2002; Laut et al., 2007). Furthermore, the test of some agglutinated species is opaque, making the observation of the stained protoplasm difficult.

The diversity $(H)$ along the estuary showed the same range of values observed in other estuarine regions with a great amount of freshwater (Laut et al., 2011a). However, a small variation of diversity $H^{\prime}$ can be identified along the estuary, which reflects the absence of a thecamoebians domain in confined environments, and the presence of a foraminifera domain in open environments (Caeté Bay), as in Araguari Estuary.

Assemblages $\mathrm{A}$ and $\mathrm{B}$, identified by $\mathrm{R}$-mode cluster analysis, were found in the middle and upper parts of estuary; assemblages D and $\mathrm{E}$, which include herbivorous species (Boltovskoy, 1965), were found in the muddy sand of mangroves (Laut et al., 2011a, b); assemblages C and G are made up of mangrove fringe species (Laut et al., 2011a). Q-mode cluster analysis generated groups of stations without a continuous distribution. This means that the station distribution did not follow a continuous environmental gradient (Figure 3), which is commonly observed in other Brazilian estuaries (Laut et al., 2007, 2010, 2011a, b; Marcondes-Souza et al., 2010). The station groups formed by Q-mode cluster analysis represent few differences related to freshwater supply and mangrove distance. Group I represents all the estuary, represented by all species that occur in the studied stations. Group II and III are very similar, according to their assemblage composition. The major difference is related to the presence of typical mangrove species (assemblages D and G) at Group III. The stations of Group II possibly receive more freshwater supply. Group IV appears isolated, because it is the only group dominated by $M$. fusca. Assemblages dominated by M. fusca and thecamoebians are common in the innermost regions of several microtidal estuaries (Madeira-Falcetta, 1974; Eichler-Coelho et al., 1997; Bonetti and Eichler, 1997), but this pattern was not found in the Caeté estuary.

On the basis of the position of the species in the DCA plot, species $A$. dilatatus, $A$. tepida and $A$. cassis have their occurrence favored by increases in mud, organic matter and salinity values, while species Plagiopyxis spp., Q. seminula, E. excavatum, C. impressa and B. translucens have their occurrence favored by sandy sediment, saltier water and lower organic matter. Laut et al. (2016) suggest that the principal environment pattern to foraminiferal and thecamoebians community distribution in tropical estuaries is the quality and quantity of organic matter. According to the same authors, Ammonia tepida, for instance, shows preference for bacterial sulfate reduction, which is common in environments rich in organic matter and fine sediment fractions.

The minor differences in the distribution of foraminiferal and thecamoebian species, and the environmental parameters along the estuary, suggest that the Caeté estuary is a well-mixed estuary, where it is not possible to distinguish a marked estuarine gradient. However, four environmental sectors can be identified according to the concentration of fine sediments, organic matter and salinity, that, in turn, reflect differences in the biota.

\section{Conclusion}

The Caeté River Estuary did not show a marked gradient from the inner zone to the ocean. The dominance of moderately sorted sandy sediment indicates a high hydrodynamism, except in the intermediate regions, where fine sediment grains and the highest values of organic matter were found.

The dispersion of thecamoebian species, such as Difflugia spp., in the estuary indicates an efficient distribution and transport from the freshwater sector along the principal channel. The species of thecamoebians $C$. 
impressa, C. constricta, L. vas and Plagiopyxis spp. ware associated with sandy sediment, higher $\mathrm{pH}$, and partially with temperature and salinity. On the other hand, Difflugia spp. was associated with sandy sediment, high $\mathrm{pH}$ and low temperature and salinity. Exotic foraminiferal species from the adjacent shelf, common in mesotidal estuaries, were not found in Caeté. The dominance of typical paralic environmental communities was found, where M. fusca and A. mexicana were the most common and abundant species. The calcareous species were associated with high salinity, temperature and $\mathrm{pH}$ values. Ammonia tepida was the only calcareous species associated with mud sediment and TOM. The species E. macrescens, T. salsa, A. salsum, W. palustris, $A$. pseudocassis, $A$. dilatatus, T. paranaguaensis and M. fusca were associated with muddy sediment and TOM, and the other agglutinated species were associated with sandy sediments. Four environmental regions were identified, based on biotic and abiotic analysis, but they did not follow the classic estuarine gradient. The differences were related to freshwater supply and mangrove distance. Group I represents all the estuary, since it is composed of all species that occur in the studied stations. Group II is related to more freshwater abundance and mangrove species; Group III was composed only of mangrove species. Group IV appears isolated, because it was the only group dominated by $M$. fusca and muddy sediment.

\section{Acknowledgments \\ The financial support for writing this paper was provided by the National Council of Technological and Scientific Development-CNPq (\# 445830/2014-0).}

\section{References}

Alve, E., 1995. Benthic foraminiferal responses to estuarine pollution: A review. Journal of Foraminiferal Research, 25, 190-203.

Boltovskoy, E., 1965. Los foraminiferos recientes. Eudeba, Buenos Aires, p 510.

Boltovskoy, E., Giussani, G., Watanabe, S., Wright, R. 1980. Atlas of benthic shelf foraminifera of the Southwest Atlantic. Springer, Netherlands, Holanda, 154 pp.

Bonetti, C., Eichler, B.B., 1997. Benthic foraminifers and thecamoebians as indicators of River-Sea gradients in the estuarine zone of Itapitangui River, Cananéia (SP, Brazil). Anais da Academia Brasileira de Ciências, 69, 545-563.

Brönnimann, P., Moura, J.A. \& Dias-Brito, D., 1981a. Estudos Ecológicos na Baía de Sepetiba, Rio de Janeiro, Brasil: Foraminíferos. In: Congresso Latino-Americano de Paleontologia, Porto Alegre, RS, 75-861.
Brönnimann, P., Moura, J.A. \& Dias-Brito, D., 1981 b. Foraminíferos da Fácies Mangue da Planície de Maré de Guaratiba, Rio de Janeiro, Brasil. In: Congresso LatinoAmericano de Paleontologia, Porto Alegre, RS, 91-861.

Brönnimann, P., Moura, J.A. \& Dias-Brito, D., 1981c. Ecologia dos Foraminíferos e Microrganismos Associados da Área de Guaratiba/Sepetiba: Modelo Ambiental e sua Aplicação na Pesquisa de Hidrocarbonetos. Relatório 3549, Petrobras, 81 pp.

Byers, C., Mills, E.L., Stuart, P.L., 1978. A comparison of methods of determining organic carbon in marine sediments, with suggestions for standard methods. Hydrobiology, 58(1), 43-47.

Closs, D., 1964. Ecological distribution of foraminifera and thecamoebian in the Patos Lagoon, Southern Brazil. Archivio di Oceanografia e Limnologia, Venise, 13, 297-302.

Cohen, M., Filho, P., Lara, R., Behling, H., Angulo, R., 2005. A Model of Holocene Mangrove Development and Relative Sealevel Changes on the Bragança Peninsula (Northern Brazil). Wetlands Ecology and Management, 13, 433-443.

Cohen, M.C.L., Lara, R.J., Ramos, J.F.F., Dittmar, T., 1999. Factors in unending the variability of magnesium, calcium and potassium in waters of a mangrove creek in Bragança, North Brazil. Mangroves and Salt Marshes, 3, 9-15.

Cushman, J.A., Brönnimann, P., 1948. Contributions from the Cushman Laboratory for Foraminiferal Research. Foraminiferal Research Special Publication, 34, 15-21.

Debenay, J.P., Guiral, D., Parra, M., 2004. Behaviour and taphonomic loss in foraminiferal assemblages of mangrove swamps of French Guiana. Marine Geology, 208, 295-314.

Debenay, J.P., Carbonel, P., MorzadecKerfourn, M.T., Cazaubon, A., Denèfle, M., Lézine, A.M., 2003. Multibioindicator study of a small estuary in Vendée (France). Estuarine, Coastal and Shelf Science, 58, 843-860.

Debenay, J.P., Guiral, D., Parra, M., 2002. Ecological factors acting on the microfauna in mangrove swamps. The case of foraminiferal assemblages in French Guiana. Estuarine and Costal Shelf Science, 55(4), 509-533.

Debenay, J.P., Guillou, J.J., 2002. Ecological transitions indicated by foraminiferal assemblages in paralic environment. Estuaries, 25, 1107-1120.

Debenay, J.P., Tsakiridis, E., Soulard, R., Grossel, H., 2001. Factor determining the distribution of foraminiferal assemblages in Port Joinville Harbor (Ile d'Yeu, France): the influence of pollution. Marine Micropaleontology, 43, 75-118.

Diele, K., Smith, D.J.B., 2006. Salinity tolerance of northern Brazilian mangrove crab larvae, Ucides cordatus (Ocypodidae): Necessity for larval export? Estuarine, Coastal and Shelf Science, 68, 600-608.

Duleba, W., Coimbra, J.C.S.C., Petri, S., Barbosa, C.F., 2005. Foraminíferos, tecamebas e ostracodes recentes utilizados como bioindicadores em estudos ambientais brasileiros. In: Souza, C.R.G., Suguio, K, Oliveira, A.M.S.O. \& Oliveira, P.E. (eds), Quaternário do Brasil. Holos, Ribeirão Preto, 176-210.

Eichler, B., Bonetti, C., 1995. Distribuição dos foraminíferos e tecamebas ocorrentes no manguezal do Rio Baguaçu, Cananéia, 
São Paulo - relações com parâmetros ambientais. Pesquisas, 22(1-2), 32-37.

Eichler-Coelho, P. B., Duleba, W., Eichler, B. B., Coelho-Júnior, C. 1997. Determinação do impacto ecológico do valo grande (Iguape, SP) a partir das associações de Foraminíferos e Amebas testáceas. Revista Brasileira Biologia, São Carlos, 57, 463-477.

Ellison, R.L., Broome, R., Oglivie, R., 1986. Foraminiferal response to trace metal contamination in the Patapsco River and Baltimore Harbor, Maryland. Marine Pollution Bulletin, 17, 419-23.

Fatela, F., Taborda, R., 2002. Confidence limits of species proportions in microfossil assemblages. Marine Micropaleontology, 45(2), 169-174.

Fernandes, M.E.B., 2005. Os manguezais da costa norte brasileira. Fundação Rio Bacanga, São Luis, 165.

Fisch, G., Marengo, J. M., Nobre, C. A. 1998. Uma revisão geral sobre o clima da Amazônia. Acta Amazônica, 28, 101-126.

Flemming, B.W., 2000. A revised textural classification of gravelfree muddy sediments on the basis ternary diagrams. Continental Shelf Research, 20, 1125-1137.

Geslin, E., Debenay, J.P., Duleba, W., Bonetti, C., 2002. Morphological abnormalities of foraminiferal tests in Brazilian environments: comparison between polluted and non-polluted areas. Marine Micropaleontology, 45, 151-168.

Klisa, D.A., Schöder-Adams, C.J., 1999. Holocene thecamoebians in freshwater lakes on Bylot Island, Northwest Territories, Canada. Journal of foraminiferal Research, 29(1), 26-36.

Laut, L.L.M., Martins, V., Silva, F.S., Crapez, M.A.C., Fontana, L.F., Carvalhal-Gomes, S.B.V., Souza, R.C.L., 2016. Foraminifera, thecamoebians, and bacterial activity in polluted intertropical and subtropical Brazilian estuarine systems. Journal of Coastal Research, 32, 56-69.

Laut, L.L.M., Silva, F.S., Martins, V., Rodrigues, M.A.C., Mendonça, J.O., Clemente, I.M.M.M., Laut, V.M., Mentzigen, L.G., 2012. Foraminíferos do Complexo Sepetiba/Guaratiba. In: Rodrigues, M.A.C., Pereira, S.D. and Santos, S.B. (Eds.), Baía de Sepetiba, estado da arte. Corbã, Rio de Janeiro, 115148.

Laut, L.L.M., Silva, F.S., Figueiredo Jr., A.G., Laut, V.M., 2011a. Assembléias de foraminíferos e tecamebas associadas a análises sedimentológicas e microbiológicas no delta do rio Paraíba do Sul, Rio de Janeiro. Pesquisas em Geociências, 38, 251-268.

Laut, V.M., Laut, L.L.M., Silva, F.S., Clemente, I.M.M.M., Mentzingen, L.G., Rodrigues, M.A.C. 2011b. Foraminíferos e tecamebas do estuário do rio Suruí, Baía de Guanabara, Rio de Janeiro - Brasil. In: Carvalho I.S., Srivastava N.K., Strohschoen Jr. O., Lana, C.C. (Eds.). Paleontologia: Cenários da Vida, 3, Interciência, Rio de Janeiro, 241-252.

Laut, L.L.M., Ferreira, D.E.S., Santos, V.F., Figueiredo Jr., A.G., Carvalho, M.A., Silveira, O.F.M., 2010. Foraminíferos, tecamebas e palinomorfos com indicadores da hidrodinâmica no estuário do rio Araguari, costa amazônica, estado do Pará, Brasil. Anuário do Instituto de Geociências, 3, 52-65.

Laut, L.L.M., Silva, F.S., Bonetti, C., Figueiredo Jr., A.G., Crapez, M.A.C., 2007. Foraminíferos e atividade bacteriana aplicados no diagnóstico ambiental do Estuário do Rio Itacorubí, Florianópolis, SC. Revista Brasileira de Geociências, 37, 565578.

Leipnitz, I.I., Ferreira, F., Leão, C.J., Armynot du Châtelet, R., Frontalini, F., 2014. Foraminiferal and testate amoeba diversity, distribution and ecology in transitional environments of the Tramandaí Basin (Rio Grande do Sul, South Brazil). Marine Biodiversity. doi: 10.1007/s12526-014-0243-2

Le Xuan, T., 1996. La zone sud du delta du Mekong. Sédi mentation actuelle et évolution récente. Ph.D. thesis, Bordeaux University.

Loeblich, A.R., Tappan, H., 1987. In: Foraminiferal Genera and Their Classification, vol. 2. Van Nostrand Reinhold Company, New York, 1182 pp.

Madeira-Falcetta, M. 1974. Ecological distribution of the thecamoebal and foraminiferal associations in the mixohaline environments of the southern Brazilian littoral. Anais da Academia Brasileira de Ciências, 46(3-4), 667-687.

Magalhães, A., Costa R.M., Liang, T.H., Pereira L.C., Ribeiro, M.J.S., 2006. Spatial and temporal distribution in density and biomass of two Pseudodiaptomus species (Copepoda: Calanoida) in the Caeté river estuary (Amazon, region North of Brazil). Brazilian Journal of Biology, 66(2), 421-430.

Marcondes-Souza, V., Laut, L.L.M., Silva, F.S., Figueiredo Jr., A.G., Vital, H., Frazão, E., 2010. Benthic Foraminifera and Bacterial Activity as a Proxy for Environmental Characterization in Potengi Estuary, Rio Grande do Norte, Brazil. Anuário do Instituto de Geociências, 33, 20-34.

Monteiro, M.C., Pereira L.C.C. \& Oliveira S.M.O. 2009. Morphodynamic Changes of a Macrotidal Sand Beach in the Brazilian Amazon Coast (Ajuruteua-Pará). Journal of Coastal Research, Special Issue 56, 103-107.

Murray, J.W., Bowser, S.S., 2000. Mortality, protoplasm decay rate, and reliability of staining techniques to recognize 'living' foraminifera: a review. Journal of Foraminiferal Research, 30, 66-70.

Nascimento Jr., W.R., Souza-Filho, P.W.M., Proisy, C., Lucas, R.M., Rosenqvist, A., 2013. Mapping changes in the largest continuous Amazonian mangrove belt using object-based classification of multisensor satellite imagery. Estuarine, Coastal and Shelf Science, 117, 83-93.

Schafer, C.T., Collins, E.S., Smith, N.J., 1991. Relationship of foraminifera and thecamoebian distribution to sediments contaminated by pulp mill effluent: Saguenary Fjord, Quebec, Canada: Marine Micropaleontology, 17, 255-283.

Scott, D.B., Schafer, C.T., Medioli, F.S., 2001. Monitoring in Coastal Environments using Foraminifera and Thecamoebian Indicators. Cambridge University Press, Cambridge.

Scott, D.B., Schnack, E.J., Ferrero, L., Espinosa, M., and Barbosa, C.F. 1990. Recent Marsh Foraminifera from the East Coast of South America: Comparison to the Northern Hemisphere, In Hemleben et al. (eds.), Paleoecology, Biostratigraphy, Paleooceanography, and Taxonomy of agglutinated foraminifera, Kluwer Academic Publishers, Netherlands, Proceedings of NATO ASI/Series C. 717-738. 
Scott, D.B., Medioli, F.S., 1980. Living vs. total foraminiferal populations: their relative use fullness in paleoecology. Journal of Paleontology, 54, 814-831.

Sharifi A.R., Croudace I.W., Austin, R.L. 1991. Benthic foraminiferids as pollution indicators in Southampton Water, southern England, UK. Journal of Micropaleontology, 10, 109113.

Souza-Filho, P.W.M., Lessa, G.C., Cohen, M.C.L., Costa, F.R., Lara, R.J., 2009. The Subsiding Macrotidal Barrier Estuarine System of the Eastern Amazon Coast, Northern Brazil. In: Dillenburg, S.F., Hesp, P.A. (Eds.), Geology and Geomorphology of Holocene Coastal Barriers of Brazil. Springer, New York, 347-375.

Souza-Filho, P.W.M., Cohen, M.C.L., Lara, R.J., Lessa, G.C., Koch, B., Behling, H., 2006. Holocene Coastal Evolution and Facies Model of the Bragança Macrotidal Flat on the Amazon Mangrove Coast, Northern Brazil. Journal of Coastal Research, Special Issue, 39, 306-310.

Souza Filho, P.W.M., Paradella, W.R., 2003. Use of synthetic aperture radar for recognition of Coastal Geomorphological Features, land-use assessment and shoreline changes in Bragança Coast, Pará, Northern Brazil Anais da Academia Brasileira de Ciências, 75(3), 341-356.

Souza Filho, P.W.M., Paradella, W.R., 2002. Recognition of the main geobotanical features along the Bragança mangrove coast (Brazilian Amazon Region) from Landsat TM and RADARSAT-1 data. Wetlands Ecology and Management, 10, 123-132.

Souza Filho, P.W.M., 2000. Tectonic control on the coastal zone geomorphology of the northeastern Pará State. Revista Brasileira de Geociências, 30, 523-526.

Souza Filho, P.W.M., El-Robrini, M., 1998. As variações do nível do mar e a estratigrafia de seqüências da Planície Costeira Bragantina - Nordeste do Pará, Brasil. Boletim Museu Paraense Emílio Goeldi, 10, 1-34.
Souza Filho, P.W.M., El-Robrini, M., 1996. Morfologia, processos de sedimentação e litofácies dos ambientes morfosedimentares da Planície Costeira Bragantina - Nordeste do Pará (Brasil). Geonomos, 4, 1-16.

Suguio, K. (Ed.), 1973. Introdução a Sedimentologia. Edgard Blücher/EDUSP, São Paulo, 317 pp.

Todd, R., Brönnimann, P., 1957. Recent Foraminifera and Thecamoebian from the Eastern Golf of Praia, Trinidad. Cushman Foundation for Foraminifera Research. Foraminifera Research Special Publication, 3, 1-43

Vilela, C.G., Koutsoukos, E.A.M., 1995. Quaternary benthic foraminiferal morphologroups and trophic structures from the Amazon Delta: A preliminary Report. Anais da Academia Brasileira de Ciências, 67(3), 387-388.

Walker, I. 1982. The thecamoebae (Protozoa, Rhizopoda) of small Amazonian Forest streans and their possible use as indicator organisms for water quality. Acta Amazonica, 12:79105.

Walker, W.R., Lages, M.T., 1980. Adaptation of constant effort sampling and of removal trapping for the estimation of populations of microscopic organisms in dense populations. Acta Amazônica, 10(3), 44-535.

Wang, P., Chappell, J., 2001. Foraminifera as Holocene environmental indicators in the South Alligator River, north Australia. Quaternary International, 83(85), 47-62.

Wang, P., Murray, J.W., 1983. The use of foraminifera as indicators of tidal effects in estuarine deposits. Marine Geology, 51, 239-250.

Yanko, V., Ahmad, M., Kaminsky, M., 1998. Morphological deformities of benthic foraminiferal tests in response to pollution by heavy metals: implications for pollution monitoring. Journal of Foraminiferal Research, 28, 177-200.

Yanko, V., Kronfeld, J., Flexer, A., 1994. Response of benthic foraminifera to various pollution sources: implications for monitoring. Journal of Foraminiferal Research, 24(1), 1-17. 
Supplementary material 1. Biotic variables recorded in the studied stations of Caeté River Estuary.

\begin{tabular}{|c|c|c|c|c|c|c|c|c|c|c|c|c|c|c|c|c|c|c|c|c|}
\hline Species/Stations & CA01 & CA02 & CA03 & CA04 & CA05 & CA06 & CA07 & CA08 & CA09 & CA10 & CA11 & CA12 & CA13 & CA14 & CA15 & CA16 & CA17 & CA18 & CA19 & CA22 \\
\hline Number of specimens/ $150 \mathrm{ml}$ & 261 & 564 & 168 & 618 & 783 & 384 & 240 & 981 & 151 & 2754 & 1803 & 435 & 150 & 3399 & 1503 & 1134 & 216 & 843 & 154 & 630 \\
\hline Number of species & 16 & 20 & 6 & 10 & 16 & 13 & 14 & 18 & 5 & 27 & 22 & 12 & 4 & 18 & 10 & 21 & 10 & 19 & 5 & 9 \\
\hline Shannon diversity $\left(H^{\prime}\right)$ & 1.6 & 1.7 & 0.5 & 1.1 & 1.3 & 1.4 & 1.6 & 1.5 & 0.9 & 1.6 & 1.4 & 1.1 & 0.9 & 1.5 & 0.6 & 1.4 & 1.3 & 1.9 & 0.7 & 0.6 \\
\hline Evenness $\left({ }^{\prime}\right)$ & 0.6 & 0.6 & 0.3 & 0.5 & 0.5 & 0.6 & 0.6 & 0.5 & 0.6 & 0.5 & 0.4 & 0.4 & 0.7 & 0.5 & 0.2 & 0.5 & 0.5 & 0.7 & 0.5 & 0.3 \\
\hline Stained tests & 0 & 2 & 0 & 2 & 0 & 1 & 0 & 0 & 1 & 7 & 3 & 1 & 0 & 0 & 3 & 7 & 0 & 6 & 0 & 1 \\
\hline Abnormality forms & 1 & 7 & 0 & 12 & 11 & 2 & 3 & 13 & 2 & 22 & 10 & 4 & 1 & 15 & 32 & 11 & 1 & 5 & 3 & 3 \\
\hline Ammoastuta inepta & - & - & 2.2 & 3.9 & 2.3 & 1.6 & - & 3.7 & - & 2.0 & 2.5 & 3.4 & - & 3.6 & 0.5 & 2.4 & 2.8 & 2.1 & 2.4 & 1.9 \\
\hline Ammoastuta salsa & - & - & - & 2.4 & 0.4 & - & - & 1.2 & - & 0.5 & 1.5 & 0.7 & - & 2 & - & - & - & - & - & 1.0 \\
\hline Ammobaculites dilatatus & - & - & - & - & - & - & - & - & - & - & - & - & - & - & - & 0.4 & - & 10.0 & - & - \\
\hline Ammonia tepida & - & - & - & - & - & - & - & - & - & - & 0.2 & 0.7 & - & - & - & - & - & 1.1 & - & - \\
\hline Ammotium cassis & - & - & - & - & - & - & - & - & 6.7 & 1.0 & - & - & - & - & - & - & - & 5.0 & - & - \\
\hline Ammotium psendocassis & - & - & - & - & - & - & - & - & - & 0.3 & - & - & - & - & - & - & - & 1.4 & - & - \\
\hline Ammotium salsum & 1.1 & - & - & - & - & 1.6 & - & 1.5 & - & 1.0 & 0.3 & - & - & 1.6 & 0.5 & 0.8 & - & 0.7 & - & 1.9 \\
\hline Arenoparrella mexicana & 57.5 & 53.2 & 89.1 & 67.5 & 67.4 & 59.4 & 57.5 & 60.2 & 73.3 & 59.7 & 65.6 & 73.8 & 68.0 & 47.8 & 6.0 & 70.2 & 63.9 & 47.3 & 78.0 & 86.2 \\
\hline Haplophragmoides manilaensis & - & 1.1 & - & - & - & 1.6 & 1.3 & - & - & 0.5 & 0.8 & - & - & - & - & & - & - & - & - \\
\hline Haplophragmoides wilberti & 16.1 & 19.1 & 2.2 & 16.0 & 10.3 & 7.0 & 10.0 & 10.1 & 3.3 & 14.4 & 15.0 & 8.3 & 20.0 & 10 & 3.7 & 6.1 & 18.1 & 9.3 & 14.6 & 5.2 \\
\hline Jadammina polystoma & - & 4.8 & - & 2.9 & 6.1 & 18.8 & 11.3 & 0.6 & - & 4.5 & 0.5 & 0.7 & - & 5.6 & 1.0 & 2.4 & 4.2 & 1.1 & 2.4 & - \\
\hline Miliammina fusca & 4.6 & 5.3 & 2.2 & 4.9 & 2.7 & - & 5.0 & 14.1 & 10.0 & 8.0 & 4.3 & 7.6 & - & 7.3 & 87.3 & 5.3 & 1.4 & 4.6 & - & - \\
\hline Paratrochammina clossi & - & 2.7 & - & - & - & - & - & - & - & 0.5 & 0.2 & - & - & 1.6 & & & 1.4 & - & - & - \\
\hline Polysaccammina ipohalina & - & 1.1 & 2.2 & - & 0.8 & 0.8 & - & 0.3 & - & 0.7 & 0.5 & - & - & 1.6 & 0.2 & 0.4 & - & - & - & 1.9 \\
\hline Pseudotburammina limnetis & - & - & - & - & - & - & - & 0.3 & - & - & 0.2 & - & - & - & - & - & - & - & - & - \\
\hline Quinqueloculina seminula & - & - & - & - & - & - & - & - & - & - & - & - & - & - & - & 0.8 & - & - & - & - \\
\hline Reophax nana & - & 0.5 & - & - & - & - & - & - & - & - & - & - & - & 1.6 & - & 0.4 & - & - & - & - \\
\hline Siphotrochammina lobata & 1.1 & 0.5 & - & 0.5 & & & 1.3 & 2.1 & & 0.4 & 0.2 & - & - & 2 & - & 2.0 & 2.8 & 0.4 & - & 1.0 \\
\hline Textularia earlandi & 2.3 & - & - & - & - & 0.8 & - & 0.9 & - & 0.4 & 0.3 & 1.4 & - & 1.6 & - & 0.4 & 2.8 & 3.2 & - & - \\
\hline Textularia paranaguaensis & - & 0.5 & - & - & - & - & 1.3 & - & - & 0.1 & - & - & - & - & - & 0.4 & - & 1.1 & - & - \\
\hline
\end{tabular}


Supplementary material 1 (cont.). Biotic variables recorded in the studied stations of Caeté River Estuary.

\begin{tabular}{|c|c|c|c|c|c|c|c|c|c|c|c|c|c|c|c|c|c|c|c|c|}
\hline Species/Stations & CA01 & CA02 & $\mathrm{CA} 03$ & CA04 & CA05 & CA06 & CA07 & CA08 & CA09 & CA10 & CA11 & CA12 & CA13 & CA14 & CA15 & CA16 & CA17 & CA18 & CA19 & CA22 \\
\hline Tiphotrocha comprimata & 1.1 & 0.5 & - & 0.5 & - & 2.3 & - & - & - & 1.0 & 0.8 & - & - & - & 0.2 & - & 1.4 & - & - & - \\
\hline Trochammina inflata & 1.1 & 1.1 & - & - & 1.9 & 1.6 & 1.3 & - & 6.7 & 0.4 & 0.8 & 1.4 & 4.0 & 2 & 0.2 & 1.6 & - & 0.4 & 2.4 & 0.5 \\
\hline Entria macrescens & 3.4 & 4.3 & - & 1.0 & 3.4 & 1.6 & - & 1.2 & - & 1.0 & 2.3 & - & 8.0 & 2.6 & - & 1.2 & - & 2.5 & - & 0.5 \\
\hline Tritaxis squamata & 1.1 & 0.5 & - & - & - & 1.6 & 1.3 & - & - & 0.4 & 0.5 & - & - & 2.6 & - & - & - & 0.4 & - & - \\
\hline Trochamminita irregularis & - & - & - & - & - & - & 1.3 & 0.3 & - & 0.1 & - & - & - & - & - & - & - & - & - & - \\
\hline Trochamminita salsa & 1.1 & 1.1 & 2.2 & 0.5 & 0.4 & - & 1.3 & 0.3 & - & 0.3 & 1.0 & 1.4 & - & - & - & 0.8 & - & 0.7 & - & - \\
\hline Warrenita palustris & 2.3 & 1.1 & - & - & 1.5 & 1.6 & 1.3 & 0.9 & - & 1.0 & 2.0 & 0.7 & - & 2.6 & 0.2 & 0.8 & - & 8.5 & - & - \\
\hline Centropyxis constricta & - & - & - & - & 0.8 & - & - & - & - & 0.3 & - & - & - & - & - & - & - & - & - & - \\
\hline Cyclopyxis impressa & - & - & - & - & 0.4 & - & - & - & - & - & - & - & - & - & - & - & - & - & - & - \\
\hline Cyclopyxis spp. & - & - & - & - & - & - & - & - & - & 0.1 & - & - & - & - & - & - & - & - & - & - \\
\hline Difflugia capreolata & - & 1.1 & - & - & - & - & - & - & - & 0.5 & - & - & - & - & - & - & - & - & - & - \\
\hline Difflugia globulus & - & - & - & - & - & - & - & - & - & - & 0.2 & - & - & - & - & - & - & - & - & - \\
\hline Difflugia urceolata & 1.1 & 0.5 & - & - & - & - & 3.8 & 0.9 & - & 0.4 & - & 0.7 & - & - & - & 0.4 & 1.4 & - & - & - \\
\hline Difflugia viscidula & 1.1 & - & - & - & - & - & - & - & - & - & - & - & - & 1.6 & - & - & - & 0.4 & - & - \\
\hline Difflugia oblonga & 1.1 & 0.5 & - & - & 0.8 & - & 2.5 & 0.6 & - & - & 0.3 & - & - & - & - & - & - & - & - & - \\
\hline Pontigulasia compressa & 3.4 & 0.5 & - & - & 0.4 & - & - & 0.6 & - & 0.4 & - & - & - & - & - & - & - & - & - & - \\
\hline Plagiopyxis spp. & - & - & - & - & - & - & - & - & - & - & - & - & - & - & - & 0.4 & - & - & - & - \\
\hline
\end{tabular}

